\title{
粘土の動的圧密について
}

$\begin{array}{ccccc}\text { 正員 } & \text { 村 } & \text { 山 朔 } & \text { 郎* } \\ \text { 正員 } & \text { 柴 } & \text { 田 } & \text { 徹** }\end{array}$

\section{ON THE DYNAMIC CONSOLIDATION OF CLAY}

\author{
By Dr. Eng., Sakurō Murayama, C.E. Member and Tōru Shibata, C.E. Member
}

Synopsis: This is a report of a theoretical and experimental research on the dynamic consolidation of clay. In this paper, assuming that the clay constitution has the rheological model proposed in the preceding paper ${ }^{11}$, a fundamental formula concerning the dynamic consolidation is derived, and the experimental results are analysed in order to give some quantitative characteristics of dynamic consolidation of clay.

要旨 粘土のレオロジ一的な特性を示すために，さきに提案した力学モデル゙マ動的荷重が載荷され た場合の圧密沈下量と時間の関係 招よび 動的・静的圧密沈下量の関係を示す理論式を導いたのち, 動的 圧密の効果を支配する要素に対して考察そ行い，かつ笑験汇よつて理論の妥当性を検照した。

\section{1. 緒言}

列車振動をろける軌道路盤，交通荷重をろける舗装路艋めるいは振動を発生する機械の基礎地盤が粘性土さり なる場合の圧密現象には，例总ば動的荷重が圧密におよぼす効果，動的圧密量の推定なぞの重要な問題があるに かかわらず複雑な現象であるためと十分な解明はまだなく，二・三の理論 ${ }^{2}{ }^{3}{ }^{31}$ とよつて定性的な傾向の一端が示さ れているにすぎない現状である。

本論文はこのような現実の粘土の圧密諸特性を解明するために，粘土のレオロジー 的観点からすでて提案した力学モデル゙(図一1参照)を用いて時間的に一定でない外力 を作用させた場合の理論解を求めたのち，実験によつて解の妥当性を検照したもので ある。

\section{2. 動的圧密の理論}

Terzaghi の圧密理論の基礎仮定の一つは「土粒子の相互か及合わせ汇よて構成さ れている土粒子構造骨格は完全弾性スプリングの作用をなす」であつたが，著者らは すでて提案したごとく1〉レオロジ一的観点からこの構造骨格のモデルとしては弾性スプ

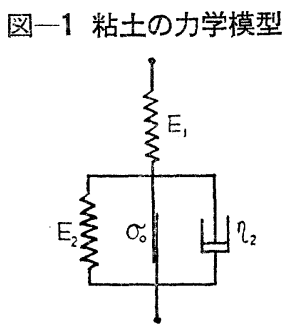
リングは適当でなくそのモデルとは図一1のような下限降伏值 $\left(\sigma_{0}\right)$ に相当するスライダーを並列に加えた Voigt 要素 (弾性係数 $E_{2}$, 粘性係数 $\eta_{2}$ ) そさらに直列に 1 個のスプリング（弾性係数 $E_{1}$ ) を組み合わせたるのを用いな ければならないととを明らがした。ただしVoigt 要素の粘性項 $\left(\eta_{2}\right)$ は単純なダッシュポットでなく、粘性式

$$
\eta_{2}=\frac{1}{A_{2} \sinh \left(\frac{B_{2} \sigma_{2}}{\sigma-\sigma_{0}}\right)}
$$

にて与兄られる構造粘性を示するのとした。ここに $A_{2}, B_{2}$; レオロジー的常数, $\sigma$; 全応力, $\sigma_{2}$; 粘性要素に加わ る応力である。

さて一次圧密と二次圧密過程では間ゲキ水圧の有無炕つて $\sigma_{2}$ の大きさに差異があるはずであるから, 便宜的 飞圧密過程を二つに分けて考察することとし，ここではとのうち一次圧密の文について解明することとする。一 次圧密, すなわち間攵キ水圧が生じている過程で怗土䊀子骨格飞加わる有効応力が小さいために Voigt 要素の 変形が粘土の压密変形汇寄与する効果るまたきわめて小さいと考えられる。従つて

$$
\sinh \left(\frac{B_{2} \sigma_{2}}{\sigma-\sigma_{0}}\right) \div \frac{B_{2} \sigma_{2}}{\sigma-\sigma_{0}}
$$

となる。また Voigt 要素のヒズミを $\varepsilon_{2}$ とすれば

$$
\frac{d \varepsilon_{2}}{d t}=\frac{1}{\eta_{2}}\left(\sigma-\sigma_{0}\right)
$$

* 工学博士, 京都大学教授, 工学部土木工学教室

** 京都大学講師, 工学部土木工学教室 
であるから式 (1) の関係より

$$
\frac{d \varepsilon_{2}}{d t}=A_{2} B_{2} \sigma_{2}
$$

となる。

さて上述の力学模型に対しクリープ方程式を誘導する。

$$
\begin{aligned}
& \varepsilon=\varepsilon_{1}+\varepsilon_{2} \cdots \cdots \\
& \sigma=\varepsilon_{1} E_{1} \cdots \cdots \cdots \cdots \cdots \cdots \cdots \cdots \cdots \\
& \sigma-\sigma_{0}=\varepsilon_{2} E_{2}+\frac{1}{A_{2} B_{2}} \frac{d \varepsilon_{2}}{d t}
\end{aligned}
$$

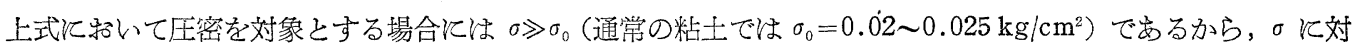
し $\sigma_{0}$ を無視すれば

$$
\sigma=\varepsilon_{2} E_{2}+\frac{1}{A_{2} B_{2}} \frac{d \varepsilon_{2}}{d t}
$$

となる。 $t=0$ で $\varepsilon_{2}=0$ の条件より式 (7) を解けば

$$
\varepsilon_{2}=\frac{\sigma}{E_{2}}\left\{1-\exp \left(-A_{2} B_{2} E_{2} t\right)\right\}
$$

式 (4) 飞式 (5), (8) を代入して

$$
\varepsilon=\frac{\sigma}{E_{1}}+\frac{\sigma}{E_{2}}\left\{1-\exp \left(-A_{2} B_{2} E_{2} t\right)\right\}
$$

を得る。

式（8）ほクリープの場合，すなわちのが一定荷重の昜合飞成立するものであるが，任意の時間的な変化荷重の 場合には重畳の原理が成立するとして Duhamel の原理とより

$$
\varepsilon_{2}=\frac{1}{E_{2}} \int_{0}^{t}\left[-\frac{\partial}{\partial t}\left[1-\exp \left\{-A_{2} B_{2} E_{2}(t-\tau)\right\}\right]\right] \sigma(y, \tau) d \tau
$$

ここに $\tau$; 時間のパラメーター, $y$; 粘土層の上面よりの鉛直深さである。従つて式 (9) は

$$
\varepsilon=\frac{\sigma(y, t)}{E_{1}}+\frac{1}{E_{2}} \int_{0}^{t}\left[-\frac{\partial}{\partial t}\left[1-\exp \left\{-A_{2} B_{2} E_{2}(t-\tau)\right\}\right]\right] \sigma(y, \tau) d \tau \text {. }
$$

となる。

式 (11)を $t$ とついて微分して

$$
\frac{\partial \varepsilon(y, t)}{\partial t}+A_{2} B_{2} E_{2} \varepsilon(y, t)-\frac{1}{E_{1}} \frac{\partial \sigma(y, t)}{\partial t}+A_{2} B_{2}\left(\frac{1}{E_{2}}-\frac{1}{E_{1}}\right) \sigma(y, t)=0
$$

一方，Darcy の法則を用い，Terzaghi の仮定「変形速度は間ゲキ水の脱水速度飞等しい」を採用すれば

$$
\frac{\partial \varepsilon(y, t)}{\partial t}=\frac{k}{r} \frac{\partial^{2} w(y, t)}{\partial y^{2}}
$$

ただし $w$; 過剩水圧, $k$; 透水係数, $r$; 間ゲキ水の単位重量である。

さら汇載荷荷重強度を $p(t)$ とすれば，

$$
p(t)=\sigma(y, t)+w(y, t)
$$

であるから, 式 (12), (13), (14) より

$$
\begin{aligned}
& \frac{\partial^{3} w}{\partial t \partial y^{2}}+A_{2} B_{2} E_{2} \frac{\partial^{2} w}{\partial y^{2}}+\frac{r}{E_{1} k} \frac{\partial^{2} w}{\partial t^{2}}-A_{2} B_{2} E_{2} \frac{\gamma}{k}\left(\frac{1}{E_{2}}-\frac{1}{E_{1}}\right) \frac{\partial w}{\partial t} \\
& =\frac{r}{E_{1} k} \frac{d^{2} p}{d t^{2}}-A_{2} B_{2} E_{2} \frac{r}{k}\left(\frac{1}{E_{2}}-\frac{1}{E_{1}}\right) \frac{d p}{d t}
\end{aligned}
$$

いま，後述の実験に使用したような乱した粘土儿対しては，非弹性的性質が非常飞多くなり，Voigt 型塑性体 のごとくらるまうことが認められている(4),ので，この場合注は式 (15) は $E_{1} \rightarrow \infty$ と掠いて

$$
\frac{\partial^{3} w}{\partial t \partial y^{2}}+A_{2} B_{2} E_{2} \frac{\partial^{2} w}{\partial y^{2}}-A_{2} B_{2} \frac{\gamma}{k} \frac{\partial w}{\partial t}+A_{2} B_{2} \frac{\gamma}{k} \frac{d p}{d t}=0
$$

となる。

さて初期条件杼よび境界条件として

$$
w(y, 0)=p(0), w(0, t)=0,\left(\frac{\partial w}{\partial y}\right)_{y=H, t}=0
$$

すなわら厚さ $H$ の粘土首が上下面をそれぞれ透水層和よび不透水層で主されている場合については式（16）を 
解くと

$$
\begin{aligned}
w(y, t)= & \frac{2}{H} \sum_{n=0}^{\infty} \frac{-s_{n} r \sin \beta_{n} y}{E_{2} k \beta_{n}{ }^{3}}\left\{p(t)+\frac{k}{A_{2} B_{2} r} \beta_{n}{ }^{2} p(0) \exp \left(s_{n} t\right)\right. \\
& \left.+s_{n} \exp \left(s_{n} t\right) \int_{0}^{t} \exp \left(-s_{n} t\right) p d t\right\} \ldots \ldots \ldots \ldots \ldots \ldots \ldots \ldots \ldots \ldots \ldots \ldots \ldots \ldots \ldots \ldots \ldots \ldots \ldots \ldots \ldots
\end{aligned}
$$

ここK

$$
s_{n}=\frac{-E_{2} k \beta_{n}^{2}}{\gamma+\frac{k}{A_{2} B_{2}} \beta_{n}^{2}}, \beta_{n}=\frac{(2 n+1) \pi}{2 H}(n=0,1,2, \cdots)
$$

でまる。

次に $p(t)$ として二種類の載荷荷重を考兄，その二例注いて解を求める。

i) 静的載荷; $p(t)=p_{s}=$ const.

$$
\begin{aligned}
& w(y, t)=\frac{2}{H} \sum_{n=0}^{\infty} \frac{-s_{n} r \sin \beta_{n} y}{E_{2} k \beta_{n}{ }^{3}}\left\{\frac{k}{A_{2} B_{2} r} \beta_{n}^{2} p \exp \left(s_{n} t\right)+p_{s} \exp \left(s_{n} t\right)\right\} \\
& =\frac{2 p_{s}}{H} \sum_{n=0}^{\infty} \frac{\sin \beta_{n} y}{\beta_{n}} \exp \left(s_{n} t\right)
\end{aligned}
$$

式 (20) 中の $s_{n}$ (式 ((19)) 飞示す) に拉いて $A_{2} B_{2}=\infty$ として粘性項を除けげ Terzaghi の解に一致する。

ii) 振動載荷; $p(t)=p_{d}=p_{0}+p_{1} \cos \omega t$ (ただし $p_{0}>p_{1}$ )

$$
\begin{aligned}
& w(y, t)=\frac{2\left(p_{0}+p_{1}\right)}{H} \sum_{n=0}^{\infty} \frac{-s_{n} \tau \sin \beta_{n} y}{E_{2} k \beta_{n}{ }^{3}}\left[\left\{\left(\frac{p_{0}}{p_{0}+p_{1}}\right)+\frac{p_{1} s_{n}{ }^{2}}{\left(p_{0}+p_{1}\right)\left(s_{n}{ }^{2}+\omega^{2}\right)}+\frac{k}{A_{2} B_{2} \tau} \beta_{n}{ }^{2}\right\} \exp \left(s_{n} t\right)\right. \\
& \left.+\frac{p_{1}}{\left(p_{0}+p_{1}\right)}\left\{\cos \omega t+\frac{s_{n}}{s_{n}^{2}+\omega^{2}}\left(-s_{n} \cos \omega t+\omega \sin \omega t\right)\right\}\right]
\end{aligned}
$$

式 (21) に和いて圧密として効果のあるのは指数関数の項のみであるから, この項を $\bar{w}(y, t)$ とふけげ

$$
\begin{aligned}
\bar{w}(y, t) & =\frac{2\left(p_{0}+p_{1}\right)}{H} \sum_{n=0}^{\infty} \frac{-s_{n} \gamma \sin \beta_{n} y}{E_{2} k \beta_{n}{ }^{3}}\left\{\left(\frac{p_{0}}{p_{0}+p_{1}}\right)+\frac{p_{1} s_{n}{ }^{2}}{\left(p_{0}+p_{1}\right)\left(s_{n}{ }^{2}+\omega^{2}\right)}+\frac{k}{A_{2} B_{2} r} \beta_{n}{ }^{2}\right\} \exp \left(s_{n} t\right) \cdots \cdots(22) \\
& =\frac{2\left(p_{0}+p_{1}\right)}{H} \sum_{n=0}^{\infty} \frac{\sin \beta_{n} y}{\beta_{n}}\left\{\frac{\left.p_{0} A_{2} B_{2} r\left(s_{n}^{2}+\omega^{2}\right)+p_{1} A_{2} B_{2} r s_{n}{ }^{2}+k\left(p_{0}+p_{1}\right)\left(s_{n}{ }^{2}+\omega^{2}\right) \beta_{n}{ }^{2}\right\}}{\left(p_{0}+p_{1}\right)\left(s_{n}{ }^{2}+\omega^{2}\right)\left(A_{2} B_{2} r+k \beta_{n}^{2}\right)}\right\} \exp \left(s_{n}{ }^{t}\right)
\end{aligned}
$$

となる。

次に粘土凰下面を基準とした圧密沈下量 $\bar{\varepsilon}_{t}$ を求めると， $\partial \bar{\varepsilon}_{t} / \partial y=\varepsilon_{t}$ であるから，

$$
d \bar{\varepsilon}_{y=0, t}-d \bar{\varepsilon}_{y=H, t}=\frac{k}{r}\left\{\left(\frac{\partial w}{\partial y}\right)_{y=0}-\left(\frac{\partial w}{\partial y}\right)_{y=H}\right\} d t
$$

上式に和いて不透水層のところでは $d \tilde{\varepsilon}_{y=H, t},\left(\frac{\partial w}{\partial y}\right)_{y=H}$ はともに0であるから，

$$
\bar{\varepsilon}_{t}=\frac{k}{r} \int_{0}^{t}\left(\frac{\partial w}{\partial y}\right)_{y=0} d t
$$

従つて i) の $p(t)=p_{s}=$ const. の場合には式 (20) の近似解として第 1 項 $(n=0)$ のるを取ると

$$
\begin{aligned}
\bar{\varepsilon}_{t \cdot s} & \fallingdotseq \frac{k}{r} \int_{0}^{t} \frac{2 p_{s}}{H} \exp \left(s_{0} t\right) d t \\
& =\frac{k}{r} \frac{2 p_{s}}{H} \frac{1}{s_{0}}\left\{\exp \left(s_{0} t\right)-1\right\}
\end{aligned}
$$

ここル

$$
s_{0}=\frac{-A_{2} B_{2} E_{2} k \pi^{2}}{4 A_{2} B_{2} r H^{2}+k \pi^{2}}
$$

である。

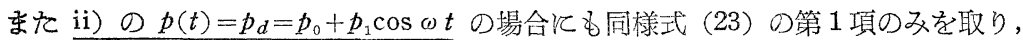

$$
\begin{aligned}
\bar{\varepsilon}_{t \cdot d} & \fallingdotseq \frac{k}{r} \frac{2\left(p_{0}+p_{1}\right)}{H s_{0}}\left\{\frac{4 H^{2} A_{2} B_{2} r p_{0}\left(s_{0}{ }^{2}+\omega^{2}\right)+4 H^{2} A_{2} B_{2} r p_{1} s_{0}{ }^{2}+k\left(p_{0}+p_{1}\right)\left(s_{0}{ }^{2}+\omega^{2}\right) \pi^{2}}{\left(p_{0}+p_{1}\right)\left(s_{0}{ }^{2}+\omega^{2}\right)\left(4 H^{2} A_{2} B_{2} r+k \pi^{2}\right)}\right\}\left\{\exp \left(s_{0} t\right)-1\right\} \\
& =\frac{k}{r} \frac{2\left(p_{0}+p_{1}\right)}{H s_{0}}\left\{\left(\frac{p_{0}}{p_{0}+p_{1}}\right)\left(\frac{1}{1+\mu}\right)+\left(\frac{\mu}{1+\mu}\right)+\left(\frac{p_{1}}{p_{0}+p_{1}}\right)\left(\frac{s_{0}{ }^{2}}{s_{0}{ }^{2}+\omega^{2}}\right)\left(\frac{1}{1+\mu}\right)\right\}\left\{\exp \left(s_{0} t\right)-1\right\}
\end{aligned}
$$


ここに

である。

$$
\mu=\frac{k \pi^{2}}{4 H^{2} A_{2} B_{2} r}
$$

式 (25) は静的圧密沈下量 $\left(\bar{\varepsilon}_{t} \cdot s\right)$ であり, 式 $(26)$ ね $\bar{\varepsilon}_{t \cdot s}$ と同一圧密時間に括ける動的圧密沈下量 $\left(\bar{\varepsilon}_{t \cdot d}\right)$ を 表わすので, $p_{d \cdot \max }=p_{0}+p_{1}$ のときの動的・静的圧密沈下量の比 $\bar{\varepsilon}_{t \cdot d} / \bar{\varepsilon}_{t \cdot s}$ を求めると,

$$
\frac{\bar{\varepsilon}_{t \cdot d}}{\bar{\varepsilon}_{t \cdot s}}=\frac{p_{0}}{p_{s}}+\left(\frac{\mu}{1+\mu}\right) \frac{p_{1}}{p_{s}}+\left(\frac{1}{1+\mu}\right)\left(\frac{s_{0}{ }^{2}}{s_{0}{ }^{2}+\omega^{2}}\right) \frac{p_{1}}{p_{s}}
$$

式 (27) の各項の值は後述の実験の結果, $H$ が数 $\mathrm{cm}$ の程度では右辺第 1 項招よび第 2 項は $10^{-1}$ のオーダー となるの対し，標準圧密試験の結果から $s_{0}=7.5 \times 10^{-2} 1 / \mathrm{min}$ であり，また振動数 $f=550 \sim 1980 \mathrm{cpm}$ の範囲 で角速度 $\omega=3.5 \times 10^{3} \sim 1.2 \times 10^{4} 1 / \mathrm{min}$ となるため第 3 項は $8.9 \times 10^{-11} \sim 8.4 \times 10^{-12}$ となつて第 1,2 項比 して無視できるので

$$
\frac{\bar{\varepsilon}_{t \cdot d}}{\bar{\varepsilon}_{t \cdot s}} \fallingdotseq \frac{p_{0}}{\dot{p}_{s}}+\left(\frac{\mu}{1+\mu}\right) \frac{p_{1}}{p_{s}}
$$

となる。従つて $\bar{e}_{t \cdot d}=\bar{e}_{t \cdot s}$ となるような動的応力と等しい圧密効果をるつ静的等価応力 $p_{e}$ は

$$
p_{e}=p_{0}+\left(\frac{\mu}{1+\mu}\right) p_{1}
$$

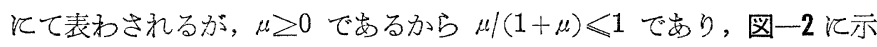

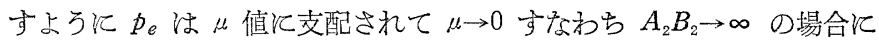
は $p_{e}=p_{0}$, た $\mu \rightarrow \infty$ すなわち $A_{2} B_{2} \rightarrow 0$ の場合飞は $p_{e}=p_{0}+p_{1}$ と なり，粘土の粘性が大きいるのほぞ動的圧密の効果は顕著である。

また式 (28) 崜動的圧密沈下量之静的圧密沈下量の関係式であつて, $\mu$ 值を知れば前者を後者から推定することが可能となる。な物 $\mu$ の值

は後述 4.のように実験によつて測定することができる。

\section{3. 試料亡実験装置}

実験に用いた試料は大阪冲積層より採取した粘土で, 初期含水量を多

図一2 等佂応力 $\boldsymbol{P}_{e}$ の説明

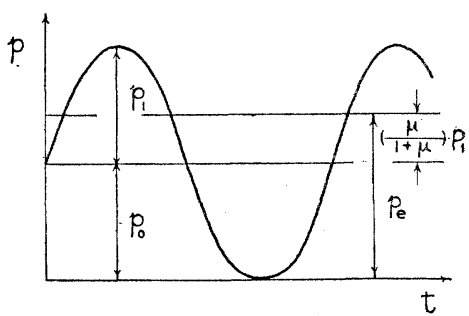

くして圧密効果を顕著ならしめるためと水を加兄つつ練返したものを使用した。物理試験の結果, 含水比 $68.2 \%$, 比重 2.629 , L.L. 108.6\%, P.L. 36.6\% となつて扮り, その粒度組成は 図一3 亿示す。

図一3 粒 径 加 積曲線

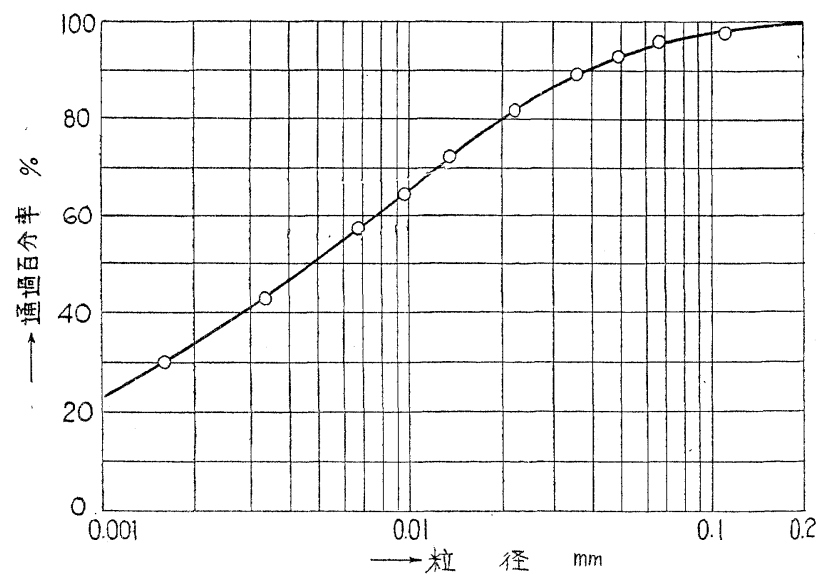

図-4＼cjkstart実験装置の概略

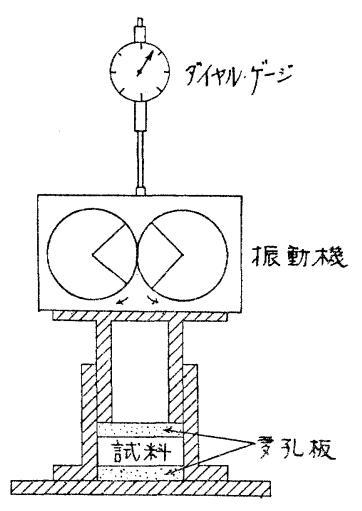

奏験装置の概略は 図一4 亿示索でときものであつて, 直径 $6.0 \mathrm{~cm}$, 厚さ $2.0 \mathrm{~cm}$ をたは $1.0 \mathrm{~cm}$ の粘土試料

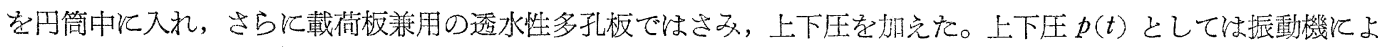
つて発生され，プランジャ一を介して試料作用される振動荷重と，振動機稆よびプランジャ一の重量とよりな るから,すでに 2. で考察した $p(t)=p_{0}+p_{1} \cos \omega t$ なる載荷方式に相当する。ここに $p_{0}$; 静的荷重強度 (振動

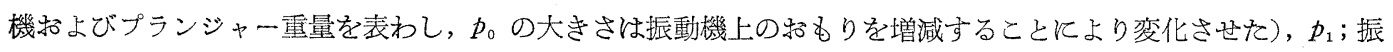
動力の最大値, $\omega$; 角速度である。振動機快 two-mass 式偏心質量型で, 偏心質量愔相可変飞なつて特り, その 駆動とは 1/8 P 可変速型モーターを用い，動力の伝導にはフレキシブル・シャフトを使用した。剆定装置として 


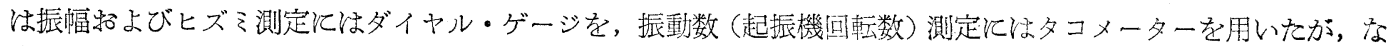
拎アスカニヤ式ハンド・ビブログラフをも併用した。

\section{4. $\mu$ 值の測定}

式 (28) を用いて動的・静的圧密沈下量の関係を求的るためには $\mu=k \pi^{2} / 4 H^{2} A_{2} B_{2} r$ の值を知ら称ばならない。 標準圧密試験の結果から

$$
\begin{aligned}
k=C_{v} \cdot m_{v} \cdot r & =\left(7.5 \times 10^{-3} \mathrm{~cm}^{2} / \mathrm{min}\right) \times\left(1.96 \times 10^{-1} \mathrm{~cm}^{2} / \mathrm{kg}\right) \times\left(10^{-3} \mathrm{~kg} / \mathrm{cm}^{3}\right) \\
& =1.47 \times 10^{-6} \mathrm{~cm} / \mathrm{min}
\end{aligned}
$$

が得られ，またレオロジ一的常数 $A_{2} B_{2}$ は次のようにして求められる。すなわち式 (9)よりとズミ速度 $(d \varepsilon / d t)$ を求めると

$$
\frac{d \varepsilon}{d t}=A_{2} B_{2} \cdot \sigma \cdot \exp \left(-A_{2} B_{2} E_{2} t\right)
$$

となるが，二次圧密過程で恃過剩水圧は消失するから $\sigma=p$ (載荷荷重強度) であり，雨辺の対数をとると

$$
\log \left(\frac{d \varepsilon}{d t}\right)=\log A_{2} B_{2} p-A_{2} B_{2} E_{2} t
$$

となる。従つて $p$ をパラメーターとして $\log (d \varepsilon / d t) \sim t$ の関係をプロットし， $t=0$ 亿対する $(d \varepsilon / d t)$ を求め ると，

$$
\left(\frac{d \varepsilon}{d t}\right)_{t=0}=A_{2} B_{2} p
$$

上式より $A_{2} B_{2}$ の值が得られるが, ここでは, 二次圧密效果は過圧密粘土のクリープ飞類似の現象であるから， 過圧密させ忌粘土を用いたクリープ試験を行つて $t$ が十分小さい時（ここでは $t \doteqdot 0$ の代りに $t=10 \sec$ をとつ

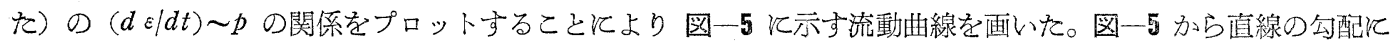
相当する $A_{2} B_{2}$ を求めると

$$
A_{2} B_{2}=5.4 \times 10^{-3} \mathrm{~cm}^{2} / \mathrm{kg} \cdot \min
$$

となり，結局

$$
\mu=\frac{k \pi^{2}}{4 H^{2} A_{2} B_{2} \gamma}=\frac{1.47 \times 10^{-6} \times \pi^{2}}{4 \times\left(\frac{1.0}{2}\right)^{2} \times 5.4 \times 10^{-6}}=2.68
$$

を得る。

図一5 ヒズミ速度と荷重強度の関係

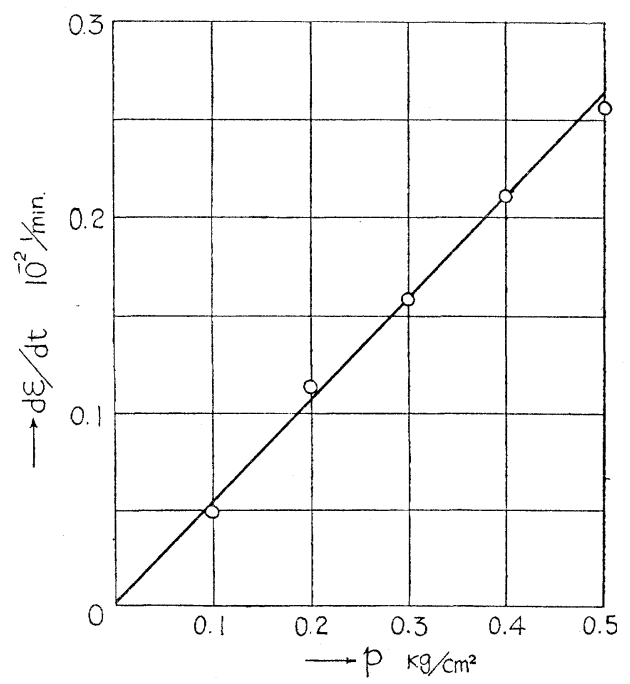

図一6＼cjkstart間ゲキ比之菏重強度の関倸

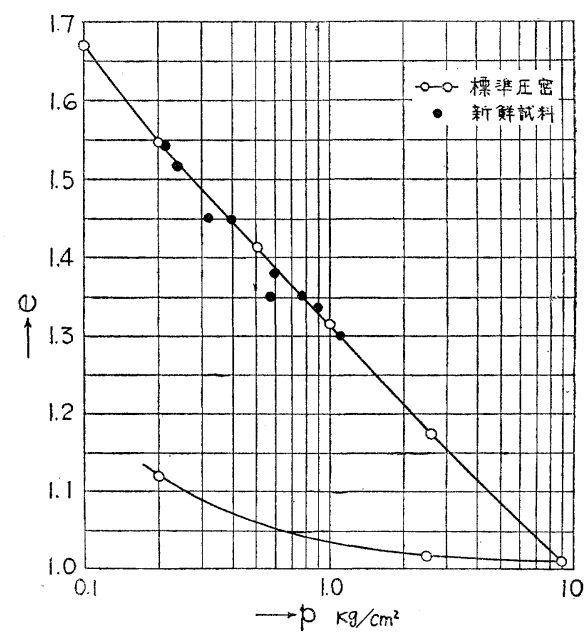

\section{5. 実験結果と考察}

まず動的圧密と比較するための標準圧密試験を行い, この結果を 図一6の○記号の点として $e \sim \log p$ 曲線を求

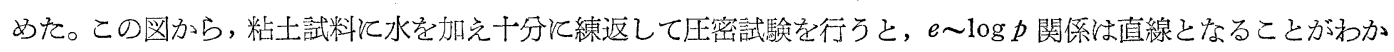
る6。な特, この図で・記号の点は各荷重段階ごとに試料を新しい乱した武料にかえて静的な圧密試験を行つた結 果であつて, 標準圧密試験のように一試料に一連の増加荷重を加えてゆく方法で得た曲線に注ぼ一致している。 
図一7 動的圧密沈下量亡時間の関係（振動数変化）

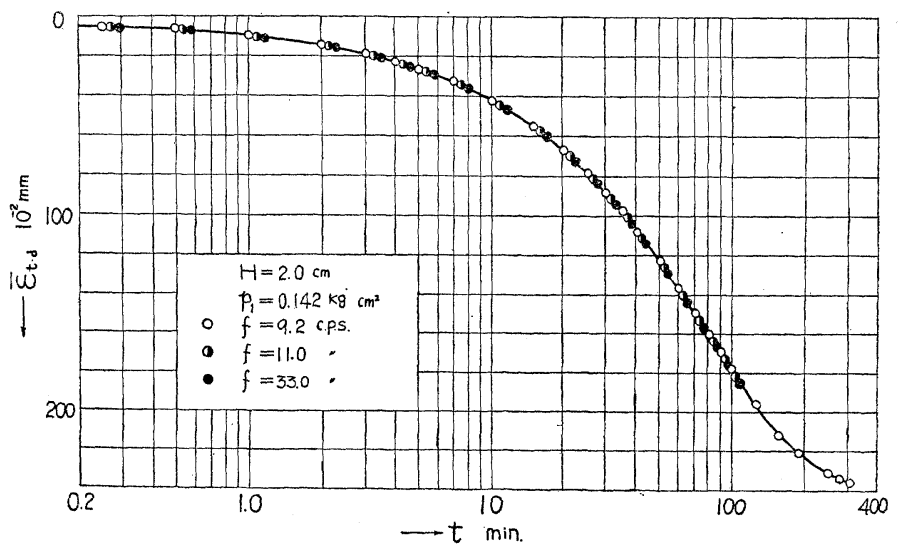

次に載荷方式 $p_{d}(t)=p_{0}+p_{1} \cos \omega t$ (ただし $p_{0}>p_{1}$ ) 飞対する圧密沈下量〜時間曲線（理論的には式((26))で表

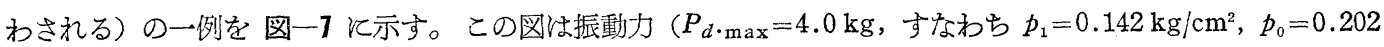
$\left.\mathrm{kg} / \mathrm{cm}^{2}\right)$ を一定にし，振動数 $f$ を $9.2,11.0,33.0 \mathrm{cps}$ の三種と変えた結果をプロットしたものであるが，圧密

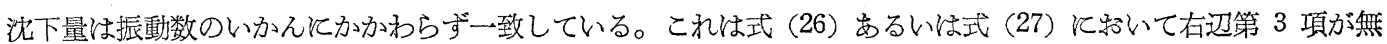
視できるために沈下量と時間の関係式には振動数の影響を含まないという結果を実証している。

次に振動力 $p_{1}$ を $0.008,0.039,0.195 \mathrm{~kg} / \mathrm{cm}^{2}$ の三種に変えて（ただしいずれの場合にも $p_{0}=0.202 \mathrm{~kg} / \mathrm{cm}^{2}$, 振動数 $f=11 \mathrm{cps}$ は一定), 動的圧密沈下量〜時間 (対数) 関係を調べた結果を 図一8 亿示す。この図から明ら かなように，振動力 $p_{1}$ が大になるぼ゙区密沈下量は当然大きくなるが，これは式（26）より

$$
\bar{\varepsilon}_{t \cdot d} \fallingdotseq \frac{k}{\gamma} \frac{2}{H s_{0}}\left\{p_{0}+\left(\frac{\mu}{1+\mu}\right) p_{1}\right\}\left\{\exp \left(s_{0} t\right)-1\right\}
$$

となつて $p_{1}$ の影響を理論的にも説明できる。しかし粘性項を無視した場合，すなわら Terzaghi の力学モデル

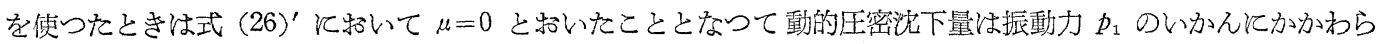
ず一定となるので 図一8の結果を説明することができない。な蛒式 $(26)^{\prime}$ の指数項 $s_{0}$ (式 (19》) に示す) Vは

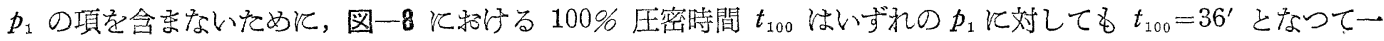
致することがわかる。

図一8 動的圧密沈下量亡時間の関䋆（振動力変化）

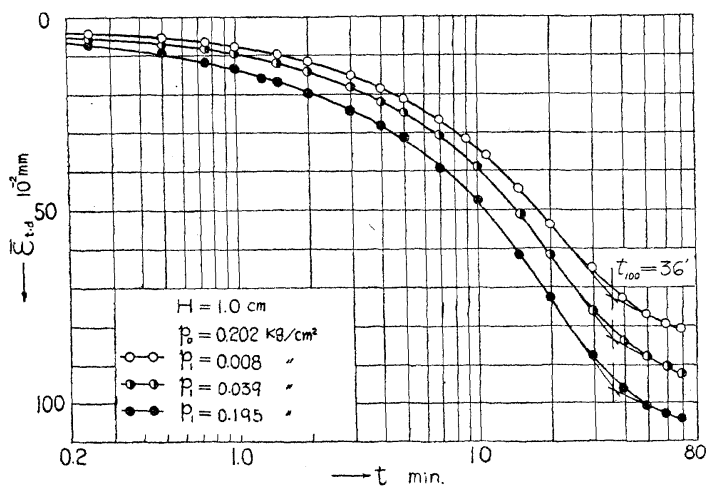

図一9100\% 区密量と荷重強度の関係

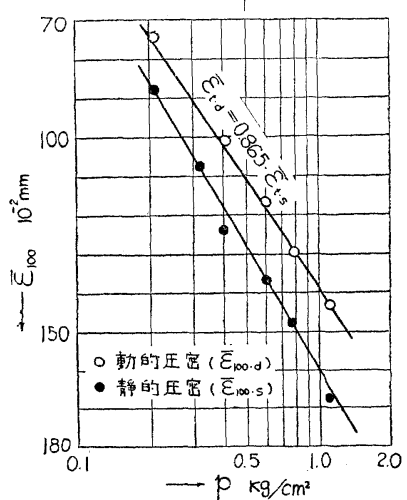

図一9 は動的・静的圧密沈下量の定量的関係を例示するために，圧密沈下量として $100 \%$ 圧密量 в $_{100}$ をとり， これと載荷荷重 $p$ との関係をプロットしたものである。この図に抬いて静的な圧密荷重による $\bar{\varepsilon}_{100 \cdot 5} \sim \log p$ 直線 は 図一6の $e \sim \log p$ 直線に対応するるのであり，動的圧密は $p_{0}=p_{1}$ の場合（すなわち振動機重量と振動力が等 しい場合）について行い, かつ $\bar{\varepsilon}_{100 \cdot d}$ 情荷荷重 $p_{d \cdot \max }=p_{0}+p_{1}$ 飞対してプロットしてある。

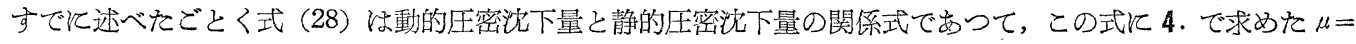
2.68 呿よび $p_{0} / p_{s}=p_{1} / p_{s}=0.5$ を代入すると

$$
\bar{\varepsilon}_{t \cdot d}=0.865 \cdot \bar{\varepsilon}_{t \cdot s}
$$


が得られる。この式沈図一-9中に示し実験結果と比較したが，両者恃よく一致することがわかり，従つて標準圧密 試験とクリープ圾験の結果を用いて動的圧密沈下量が推定できることが明らかとなつた。な叔図は省略するが， 一次圧密終了後の含水此を测定して $\log p$ との関係をプロットすをと動的・静的圧密ともに 図一 $\mathbf{9}$ と同じ傾向の 図が得られケ゚。

\section{6. 結論}

粘土のレオロジ一的な特性を示すそめさきに提案した粘土の力学モデルを適用することによつて, 粘土に動的 荷重が載荷された場合の圧密沈下量と時間，抢よび動的・静的圧密沈下量の関係を示す理論式を導いたのち，垁

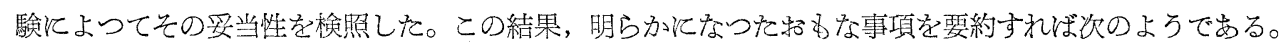

（1）動的圧密沈下量と時間の関係には振動数の影響が無視できる。

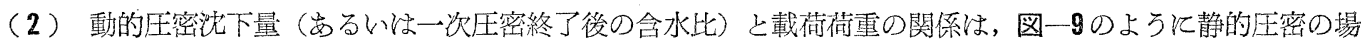
合と同様㹸片対数紙上で直線となる。

（3）（2）の動的圧密沈下量は式（28）を用いて推定できる。従つて動的圧密の効果を支配する主因子はレオ

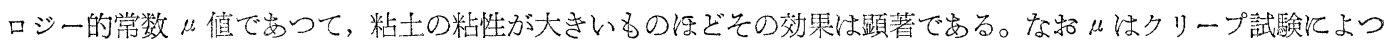
て測定することができる。

二次圧密ならびにこれとクリープとの関係については引続き次の機会を得て発表する予定である。

な特, 本研究は炤和 32 年度文部省科学研究費飞よるものの一部であり, 実験飞は京大大学院学生 浅野 茂君 の協力を得た。ここ謝意を表する次第である。

\section{参考文 献}

1）村山朔郎，柴田 徹：粘土のレオロジ一的特性について，土木学会諭交集，第 40 号，1956.

2) 村山朔郎, 谷本喜一: Dynamical Behaviour of Foundation, Disaster Prevention Research Inst., Kyoto Univ., Bulletin No. 8, pp. 18 24.

3) 最上武雄, 山口柏樹: The Theory of the Dynamical Consolidation-(1), Reports of the Inst. of Science and Technology, Tokyo Univ., Vol. 8, No. 5, 1954, pp. $209 \sim 219$.

4) 村山朔郎, 片山重夫, 天野光三：土の粘弹性について, 土木学会誌, 37 巻 5 号, 1952, pp. 219 223.

5) 村山朔郎：粘土の粘弹性について, 土木学会誌, 40 巻 7 号, 1955, pp. 344 350.

6) G.P. Tschebotarioff : Soil Mechanics, Foundations and Earth Structures, 1953, p. 257.

(昭. 33. 4. 25)

お詑び……論文集第 58 号表紙のうち, 赤井浩一氏の肩書飞, 正員 工員とあるのは正員 工博の誤植につき慎 んで訂正いたします。

正誤 表

土木学会論文集第 61 号 (昭. 34.3) 掲載

正員 工博 春日屋伸昌: 平均値法に基づく管水路内の流量算定式の誘導

\begin{tabular}{|c|c|c|c|}
\hline ペーシ & 行 & 誤 & 正 \\
\hline 39 & 下から 16 & $0.756 \mathrm{~mm}$ & $0.756 \mathrm{~m}^{\circ}$ \\
\hline 41 & 下から 20 & $R_{1}=R_{2}=\dot{R} \cdots=R_{n}$ & $R_{1}=R_{2}=\stackrel{0}{\cdots}=R_{n}$ \\
\hline 42 & 下から 8 & 残る $n-\dot{1}$ & 残る $n-1$ \\
\hline 43 & 上加 512 & 電子計算機 & 電気計算機 \\
\hline 45 & 上から 16 & $\{n ! / 1(2 n-1) !\}$ & $\{n ! /(2 n-1) !\}$ \\
\hline 46 & 参考文献 & $\begin{array}{l}\text { p. } 54, \text { p. } 15 \text {, p. } 6, \text { p. } 21, \text { p. } 300, \\
\text { p. } 59, \text { p. } 9, \text { p. } 140, \text { p. } 56,\end{array}$ & ，全全部・江訂正 \\
\hline
\end{tabular}

